\title{
POLA PERTUMBUHAN KAMBING KACANG JANTAN DI KABUPATEN KONAWE SELATAN
}

\author{
Imam Bukhori ${ }^{1}$, Rahim Aka ${ }^{2}$, Takdir Saili ${ }^{2}$ \\ ${ }^{1}$ Mahasiswa Jurusan Peternakan Fakultas Peternakan UHO \\ ${ }^{2}$ Dosen Jurusan Peternakan Fakultas Peternakan UHO \\ Email : bukhori012@gmail.com
}

\begin{abstract}
ABSTRAK
Pola pertumbuhan hewan, terutama jantan, merupakan salah satu faktor penting yang harus dipahami dengan baik oleh para peternak untuk beberapa tujuan seperti pemilihan dalam program pemuliaan atau pertimbangan keuntungan. Petani di Kabupaten Konawe Selatan yang membesarkan kambing kacang masih kekurangan informasi yang berhubungan dengan pola pertumbuhan ternak kambing khususnya kambing jantan. Oleh karena itu, tujuan dari penelitian ini adalah untuk mengevaluasi pola pertumbuhan kambing kacang jantan. Penelitian ini dilakukan di Kabupaten Konawe Selatan meliputi Kecamatan Landono, Moramo Utara dan Kecamatan Laeya selama bulan Juni-Juli 2016. Seratus empat puluh ekor kambing kacang jantan digunakan sebagai sampel dan dikelompokkan ke dalam enam kelompok umur (1-3 bulan , 4-6 bulan, 7-12 bulan, 13-24 bulan, 25-36 bulan, dan 37-48 bulan). Variabel yang diukur adalah bobot badan, lingkar dada, panjang badan, tinggi pundak, dan tinggi pinggul. Hasil penelitian menunjukkan bobot badan tumbuh sesuai dengan persamaan regresi berikut $\left(y=0,167-1,660 x+0.059 x^{2}+0,00087 x^{3}\right)$ dengan koefisien determinasi adalah 94,8\%. sementara panjang badan, lingkar dada, tinggi pundak dan tinggi pinggul kambing kacang jantan tumbuh berdasarkan persamaan regresi polinomial $\left(\mathrm{y}=25,20+1,931 \mathrm{x}-0.032 \mathrm{x}^{2} ; \mathrm{y}=\right.$ $31,59+2.383 \mathrm{x}+0.0392 \mathrm{x}^{2} ; \mathrm{y}=31,84+1.512 \mathrm{x}+0.0231 \mathrm{x}^{2} ; \mathrm{y}=32,43+1.581 \mathrm{x}-0.024 \mathrm{x}^{2}$ dengan koefisien determinasi adalah $71,8 \%, 75,6 \%, 71,7 \%$, dan 70,6\% masing-masing). Akhirnya, disimpulkan pola pertumbuhan kambing kacang jantan di Kabupaten Konawe Selatan cenderung meningkat seiring bertambahnya umur dan $94,8 \%$ faktor umur bisa menentukan bobot badan kambing kacang jantan di Konawe Selatan.
\end{abstract}

Kata kunci: Pola pertumbuhan, Kambing kacang, Jantan, Konawe Selatan.

\begin{abstract}
The growth pattern of animals, especially the male, is one of the important factor that should be understand well by the farmer or breeder for several purposes such as selection in breeding program or profit consideration. Farmers in the South Konawe Regency that raising kacang goat are stiil lack of information about the pattern of goat, especially the male goat. Therefore, the objective of this research was to evaluate the growth pattern of male kambing kacang. The research was conducted in district of konawe selatan covering sub district of landono, moramo utara and sub district of laeya during June to July 2016. One hundred forty male kambing kacang were used as samples and grouped into six groups of ages (1-3 months, 4-6 months, 7-12 months, 13-24 months, 25-36 months, and 37-48 months).Variables measured were body weight, girth, body length, shoulder height, and hip height.The results showed the body weight grew according to following regression equation $\left(y=0.167-1.660 x+0.059 x^{2}+0.00087 x^{3}\right)$ with coefficient of determination was $94.8 \%$. while body length, girth, shoulder height and hip height of male kambing kacang were growing based on the polynomial regression equation $\left(\mathrm{y}=25.20+1.931 \mathrm{x}-0.032 \mathrm{x}^{2} ; \mathrm{y}=31.59+2.383 \mathrm{x}+0.0392 \mathrm{x}^{2} ; \mathrm{y}=\right.$ $31.84+1.512 \mathrm{x}+0.0231 \mathrm{x}^{2} ; \mathrm{y}=32.43+1.581 \mathrm{x}-0.024 \mathrm{x}^{2}$ with coefficient of determination were $71.8 \%, 75.6 \%, 71.7 \%$, and $70.6 \%$ respectively). Finally, it was concluded the growth pattern of male kambing kacang in konawe selatan district tend to increase as ages increased and age factor was $94.8 \%$ could determine the body weight of male kambing kacang in konawe selatan.
\end{abstract}

Key words: Growth pattern, Kambing kacang, Male, Konawe Selatan. 


\section{PENDAHULUAN}

Salah satu ternak ruminansia kecil yang banyak dipelihara oleh peternak adalah kambing. Ternak kambing mempunyai peran strategis bagi masyarakat Indonesia khususnya di daerah pedesaan. Produksi ternak kambing di Indonesia sebagian besar diusahakan oleh petani peternak kecil di pedesaan. Ternak kambing yang diusahakan oleh petani peternak selain sebagai sumber pendapatan, ternak ini juga sangat efisien dalam mengubah hijauan pakan menjadi energi, modal usaha yang diperlukan relatif kecil dan cukup adaptif terhadap berbagai kondisi lingkungan (Marya, 2011).

Pengetahuan dalam bidang peternakan menjadi sangat penting dalam rangka pengembangan usaha peternakan. Usaha peternakan kambing merupakan salah satu usaha peternakan yang umum dilakukan oleh peternakan rakyat baik sebagai usaha sampingan maupun sebagai usaha pokok. Kambing kacang terutama kambing jantan merupakan salah satu ternak ruminansia kecil yang dipelihara sebagai ternak potong. Kambing jantan mempunyai keunggulan antara lain pemeliharaan yang mudah dan memiliki kemampuan beradaptasi tinggi terhadap berbagai keadaan lingkungan (Tidariyanti, 2013). Selain itu kambing kacang jantan juga sering di potong saat hari raya qur'ban dan juga acara aqiqah.

Namun, sering ditemukan para peternak tidak mengetahui dengan pasti perkembangan tubuh ternak kambingnya dari awal kelahiran, pemeliharaan hingga saat penjualan sehingga tidak diketahui dengan pasti produktivitas ternak dan keuntungan nominalnya yang akan dan seharusnya diperoleh. Oleh karena itu perlunya dilakukan penelitian tentang pola pertumbuhan kambing kacang jantan dengan penimbangan bobot badanya dan pengukuran dimensi tubuh ternak kambing di Kabupaten Konawe Selatan.

\section{MATERI DAN METODE}

\section{Waktu dan Lokasi Penelitian}

Penelitian ini telah dilaksanakan selama 1 (satu) bulan yaitu pada bulan Juni sampai dengan Juli 2016, bertempat di Kabupaten Konawe Selatan, Provinsi Sulawesi Tenggara.

\section{Prosedur Penelitian}

Penelitian ini dilakukan dengan metode survey. Penentuan lokasi penelitian dilakukan dengan menggunakan metode purposive sampling menurut Sugiyono (2010) yaitu teknik penentuan sampel dengan pertimbangan tertentu. Penentuan lokasi penelitian di Kabupaten Konawe Selatan dipilih tiga Kecamatan yang memiliki populasi ternak kambing kacang terbanyak, terpilih tiga kecamatan masingmasing yaitu Kecamatan Landono, Kecamatan Moramo Utara, dan Kecamatan Laeya. Penentuan sampel pada setiap desa didasarkan atas jumlah ternak kambing terbanyak yang dipelihara oleh peternak.

\section{Variabel Penelitian}

Variabel dalam penelitian ini yaitu:

1. Bobot badan (kg), ternak kambing kacang jantan umur 1-3 bulan, 4-6 bulan, 7-12 bulan, 13- 24 bulan, 25-36 bulan, dan 37- 48 bulan

2. Ukuran-ukuran dimensi tubuh ternak berdasarkan umur ternak yaitu : Lingkar dada, tinggi pundak, panjang badan, tinggi pinggul

\section{Analisis Data}

Data yang diperoleh meliputi bobot badan, panjang badan, lingkar dada, tinggi pundak, dan tinggi pinggul kemudian ditabulasi dan dianalisis secara kuantitatif dengan analisis regresi polynomial atau non linear dengan menggunakan program minitab versi 17 . 


\section{HASIL DAN PEMBAHASAN}

\section{Pola Pertambahan Bobot Badan}

Hasil penelitian menunjukkan bahwa pola pertambahan bobot badan kambing kacang jantan di Kabupaten Konawe Selatan mengikuti persamaan regresi polynomial yaitu $\mathrm{y}=0,1675-$ $1,660 x+0,059 x^{2}+0,00087 x^{3}$ dengan nilai koefisien determinan sebesar 94,8 \% . Hal ini berarti bahwa 94,8 \% bobot badan kambing kacang jantan di Kabupaten Konawe Selatan dipengaruhi oleh umur ternak. Hasil penelitian Septian dkk. (2015) menjelaskan bahwa pola pertumbuhan bobot badan kambing kacang jantan di Kabupaten Grobogan mempunyai persamaan regresi polynomial yaitu $\mathrm{y}=-0,001 \mathrm{x}^{3}-0,120 \mathrm{x}^{2}+$ $2,902 x+0,552$ dengan nilai koefisien determinasi sebesar 70,1\%.

Bobot badan kambing kacang jantan pada umur 1-3 dan 4-6 bulan terlihat bahwa pertambahan bobot badan kambing kacang jantan mengalami pertumbuhan yang cepat, karena pada umur tersebut kambing kacang jantan belum dewasa kelamin. Pada umur 7-12 bulan pertumbuhanya mulai melambat, namun masih terus meningkat sedangkan pada umur 13-24 bulan 25-36 dan umur 37-48 bulan pertumbuhanya mengalami perlambatan. Siregar (1990) menyatakan bahwa pertumbuhan yang cepat terjadi pada periode lahir hingga usia penyapihan dan pubertas, namun setelah usia pubertas hingga usia dewasa, laju pertumbuhan mulai menurun dan akan terus menurun hingga usia dewasa. Menurut Sampurna dan Suatha (2010), bahwa pertumbuhan mempunyai tahap-tahap yang cepat dan lambat, tahap cepat terjadi pada saat ternak belum dewasa kelamin, dan tahap lambat terjadi pada saat dewasa tubuh. Menurut Soeparno (2009) kambing mencapai dewasa kelamin pada umur 6-10 bulan.

Pola pertambahan bobot badan kambing kacang jantan di Kabupaten Konawe Selatan cenderung meningkat berdasarkan bertambahnya umur ternak, dapat dilihat pada Gambar 1.

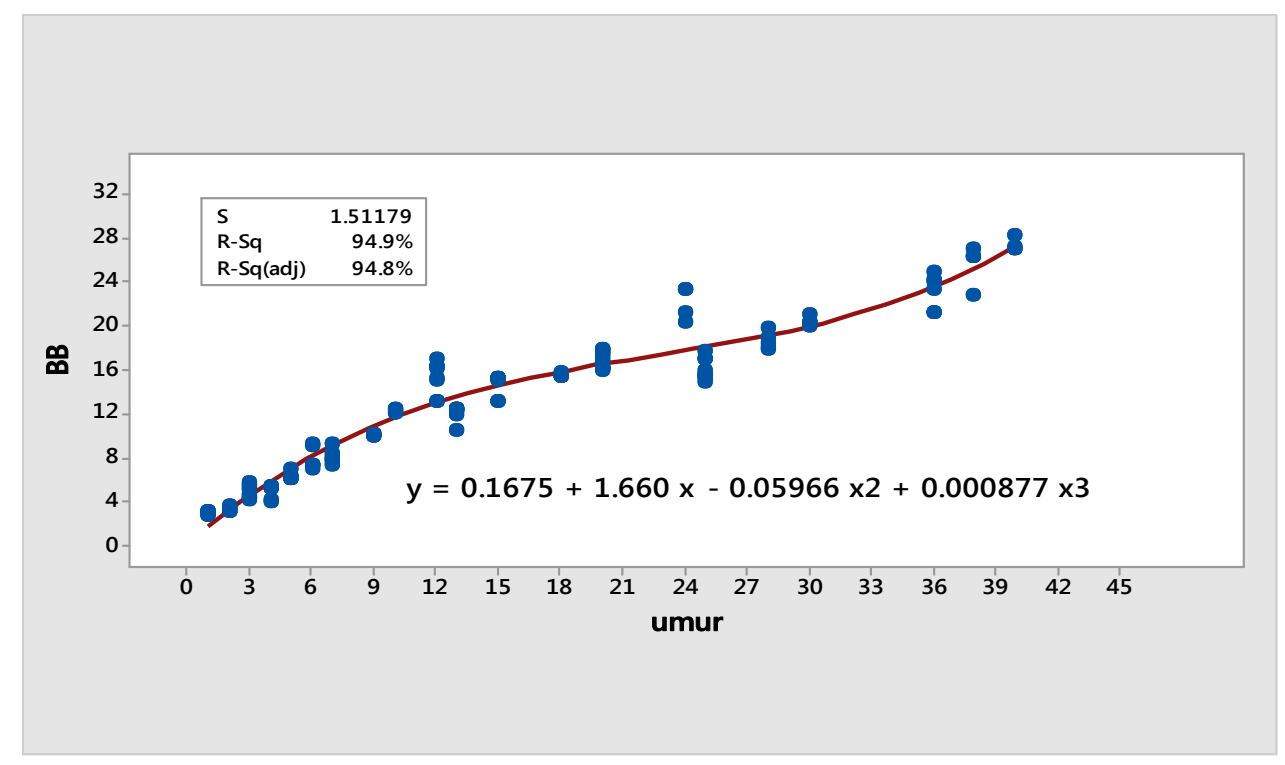

Gambar 1. Kurva pola pertambahan bobot badan kambing kacang jantan 


\section{Pola Pertumbuhan Panjang Badan}

Panjang badan kambing kacang jantan pada umur 1-3 dan 4-6 bulan mengalami pertumbuhan cepat, setelah itu pada umur 7-12 bulan masih mengalami pertumbuhan namun agak melambat dan pada umur 13-48 bulan pertumbuhan akan menjadi lambat. Hasil penelitian pola pertumbuhan panjang badan kambing kacang jantan di Kabupaten Konawe Selatan dapat dijelaskan dengan persamaan regresi polynomial yaitu $\mathrm{y}=$ $25,20+1,931 \mathrm{x}-0,032 \mathrm{x}^{2}$ dengan koefisien determinasi sebesar 72,2 \%. Hal ini berarti bahwa $71,8 \%$ panjang badan kambing kacang jantan di Kabupaten Konawe Selatan dipengaruhi oleh umur ternak.

Hasil penelitian Septian dkk. (2015), menjelaskan bahwa pola pertumbuhan panjang badan kambing kacang jantan di Kabupaten Grobogan mempunyai persamaan regresi polynomial yaitu $\mathrm{y}=-0,020 \mathrm{x}^{2}+1,293 \mathrm{x}+$ 37,07 dengan nilai koefisien determinasi sebesar 70,1\%. Hasil penelitian ini berbeda dengan hasil penelitian Rahardian (2014) yang menyatakan panjang badan kambing kacang jantan mengalami pertumbuhan cepat pada umur 3-6 bulan. Hal ini disebabkan karena pertumbuhan ternak dipengaruhi oleh berbagai faktor diantaranya bangsa, jenis kelamin, pakan, kesehatan, berat lahir, berat sapih, serta manajemen pemeliharaan. Wahyono dkk. (2013) menyatakan bahwa kondisi lingkungan yang berbeda, kesehatan ternak dan pemberian pakan yang berbeda menyebabkan pertumbuhan mengalami perbedaan.

Pola pertumbuhan panjang badan kambing kacang jantan di Kabupaten Konawe Selatan, dapat dilihat pada Gambar 2.

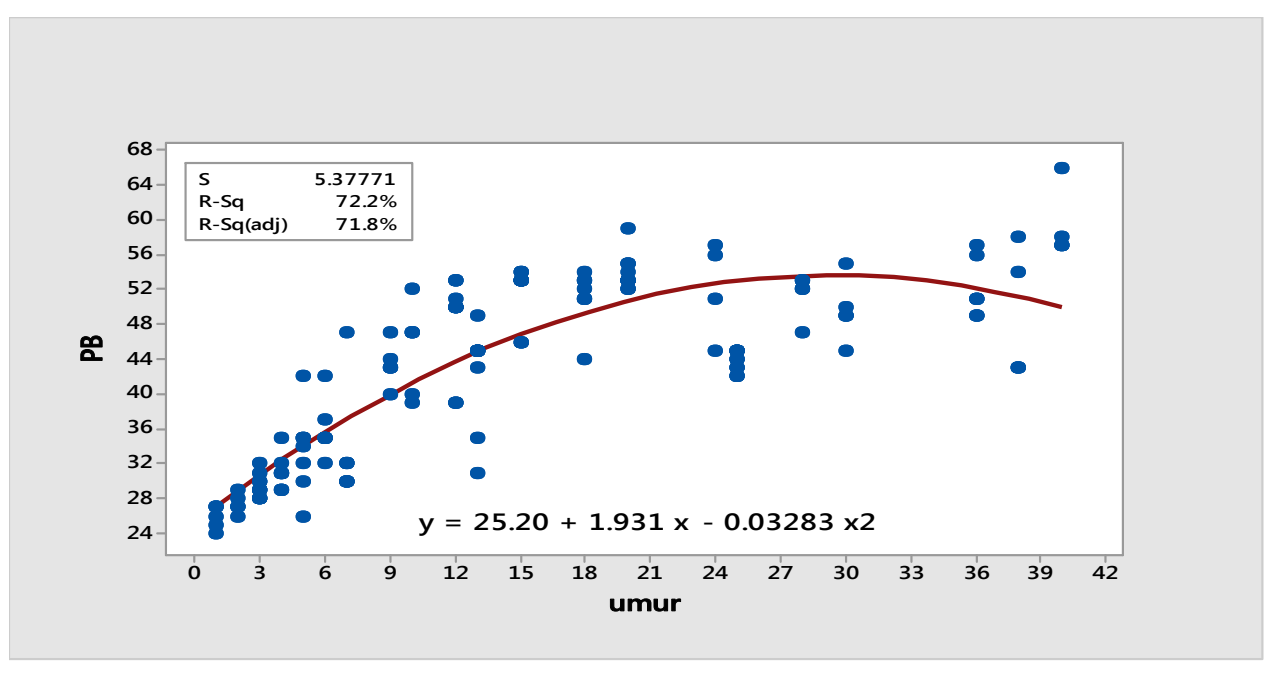

Gambar 2. Kurva pola pertumbuhan panjang badan kambing kacang jantan

\section{Pola Pertumbuhan Lingkar Dada}

Laju pertumbuhan lingkar dada kambing kacang jantan pada umur 1-3 bulan dan 4-6 bulan berlangsung cepat, setelah itu pada umur 7-12 bulan laju pertumbuhan menjadi lambat. Pertumbuhan semakin lambat pada umur 13-48 bulan. Hasil penelitian pola pertumbuhan lingkar dada kambing kacang jantan di Kabupaten Konawe Selatan dapat dijelaskan dengan persamaan regresi polynomial $\mathrm{y}=31,84+$ $1,512 x+0,0231 x^{2}$ dengan nilai koefisien determinasi sebesar 75,6\%. Hal ini berarti bahwa 75,6 \% lingkar dada kambing kacang jantan di Kabupaten Konawe Selatan dipengaruhi oleh umur ternak.

Hasil penelitian Septian dkk. (2015) menjelaskan bahwa pola pertumbuhan lingkar dada kambing kacang jantan di Kabupaten Grobogan 
mempunyai persamaan regresi polynomial yaitu $y=-0,030 x^{2}+1,107 x+42,92$ dengan nilai koefisien determinasi sebesar $64,4 \%$. Hasil penelitian ini berbeda dengan hasil penelitian Dewi (2013) pada kambing kacang betina pertumbuhan cepat terjadi pada saat ternak 0-12 bulan. Diduga perbedaan hasil penelitian disebabkan oleh pemberian pakan, manajemen pemeliharaan serta bibit yang berbeda sehingga terjadinya perbedaan kecepatan pertumbuhan. Menurut Nasution dkk. (2010) suhu yang tinggi pada musim panas yang panjang dapat mempengaruhi pertumbuhan, sebab suhu udara yang tinggi akan memperlambat metabolisme (pertukaran zat) di dalam tubuh sehingga mengganggu pertumbuhan ternak.

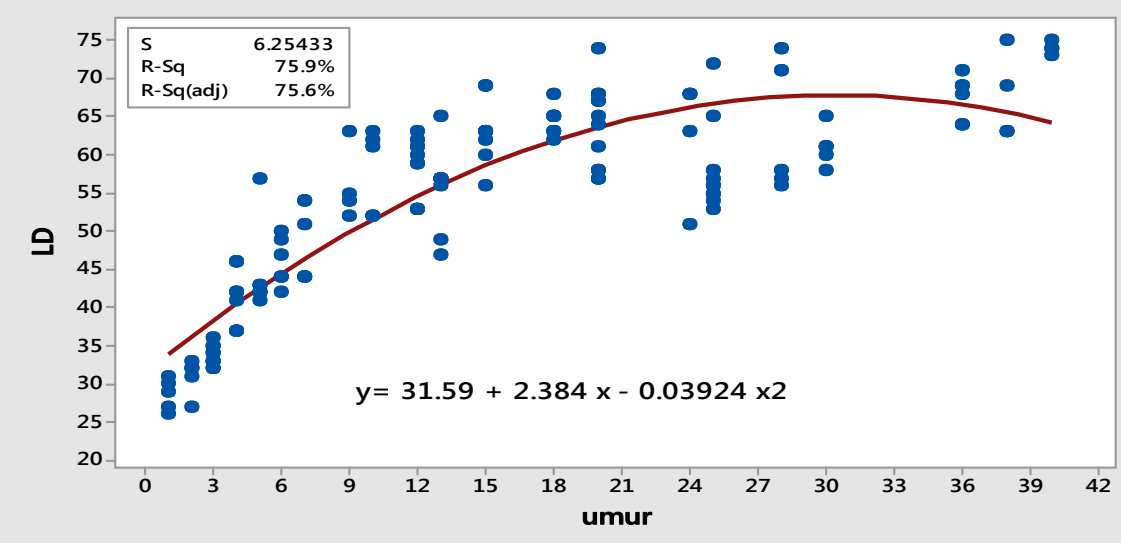

Gambar 3. Kurva pola pertumbuhan lingkar dada kambing kacang jantan

\section{Pola Pertumbuhan Tinggi Pundak}

Tinggi pundak kambing kacang jantan pada umur 1-3 bulan dan 4-6 bulan mengalami pertumbuhan cepat, setelah itu pada umur 7-48 bulan pertumbuhan akan menjadi lambat. Hasil penelitian pola pertumbuhan tinggi pundak kambing kacang jantan di Kabupaten Konawe Selatan dapat dijelaskan dengan persamaan regresi polynomial $\mathrm{y}=31,84+$ $1,512 \mathrm{x}+0,0231 \mathrm{x}^{2}$ dengan nilai koefisien determinasi sebesar $71,7 \%$. Hal ini berarti bahwa 71,7 \% tinggi pundak kambing kacang jantan di Kabupaten Konawe Selatan dipengaruhi oleh umur ternak. $\begin{array}{llr}\begin{array}{c}\text { Menurut } \\ \text { menyatakan }\end{array} & \text { Tahuk } & \text { dkk. } \\ \text { bahwa } & \text { kecepatan }\end{array}$ pertumbuhan dipengaruhi kualitas pakan yang dikonsumsi, kandungan protein dalam ransum yang tinggi meningkatkan konsumsi bahan kering yang selanjutnya digunakan untuk pertumbuhan. Syawal dkk. (2013) menyatakan bahwa faktor pakan sangat penting dalam pemenuhan kebutuhan pertumbuhan, sedangkan kekurangan pakan merupakan kendala besar dalam proses pertumbuhan. Pola pertumbuhan lingkar dada kambing kacang jantan di Kabupaten Konawe Selatan dapat dilihat pada Gambar 3. 
juga menemukan pola yang sama pada ternak sapi bagian kepala dan kaki anak sapi yang baru lahir akan berkembang lebih awal, sedangkan badanya terutama bagian punggung berkembang lebih lambat dan merupakan bagian tubuh yang tumbuh paling akhir dalam mencapai ukuran dewasa.

Sedangkan Sutiyono dkk. (2006) menyatakan bahwa pertumbuhan tulang yang relatif cepat terjadi pada tulang kepala, paha, kaki depan dan belakang, pertumbuhan tulang yang relatif sedang terjadi pada tulang rongga dada dan bahu, sedangkan pertumbuhan tulang yang relatif lambat terjadi pada tulang pinggang, dada, dan pinggul. Pola pertumbuhan tinggi pundak kambing kacang jantan di Kabupaten Konawe Selatan cenderung meningkat berdasarkan bertambahnya umur ternak, dapat dilihat pada Gambar 4.

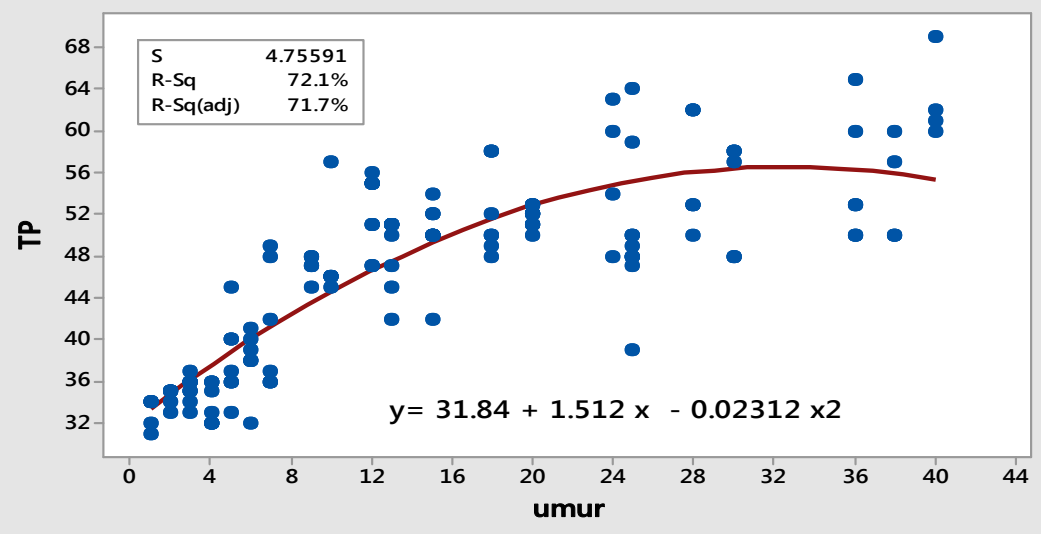

Gambar 4. Kurva pola pertumbuhan tinggi pundak kambing kacang jantan

\section{Pola Pertumbuhan Tinggi Pinggul}

Tinggi pinggul kambing kacang jantan pada umur 1-3 bulan dan 4-6 bulan mengalami pertumbuhan cepat, namun setelah pada umur 7-48 bulan pertumbuhan menjadi lambat. Hasil penelitian pola pertumbuhan tinggi pinggul kambing kacang jantan di Kabupaten Konawe Selatan dapat dijelaskan dengan persamaan regresi polynomial yaitu $\mathrm{y}=32,43+1,581 \mathrm{x}-$ $0,024 \mathrm{x}^{2}$ dengan nilai koefisien determinasi sebesar 70,6 \%. Hal ini berarti bahwa 70,6 $\%$ tinggi pinggul kambing kacang jantan di Kabupaten Konawe Selatan dipengaruhi oleh umur ternak.

Sampurna dan Suatha (2010) menyatakan dua gelombang arah tumbuh kembang pada ternak yaitu : arah anteriorposterior yang dimulai dari cranium (tengkorak) dibagian depan tubuh menuju ke belakang ke arah pinggang (loin), dan arah centripetal dimulai dari daerah kaki distalis ke arah proximal tubuh menuju bokong (pelpis) dan pinggang (loin) yang merupakan bagian tubuh yang paling akhir mencapai pertumbuhan maksimal (late maturity). Ditambahkan oleh Syawal dkk. (2013) bahwa setelah dilahirkan, bagian kepala dan kaki berkembang lebih awal, sedangkan badan terutama bagian punggung berkembang lambat dan merupakan bagian yang tumbuh paling akhir dalam mencapai ukuran dewasa.

Pola pertumbuhan tinggi pinggul kambing kacang jantan di Kabupaten Konawe Selatan cenderung meningkat berdasarkan bertambahnya umur ternak, dapat dilihat pada Gambar 5. 


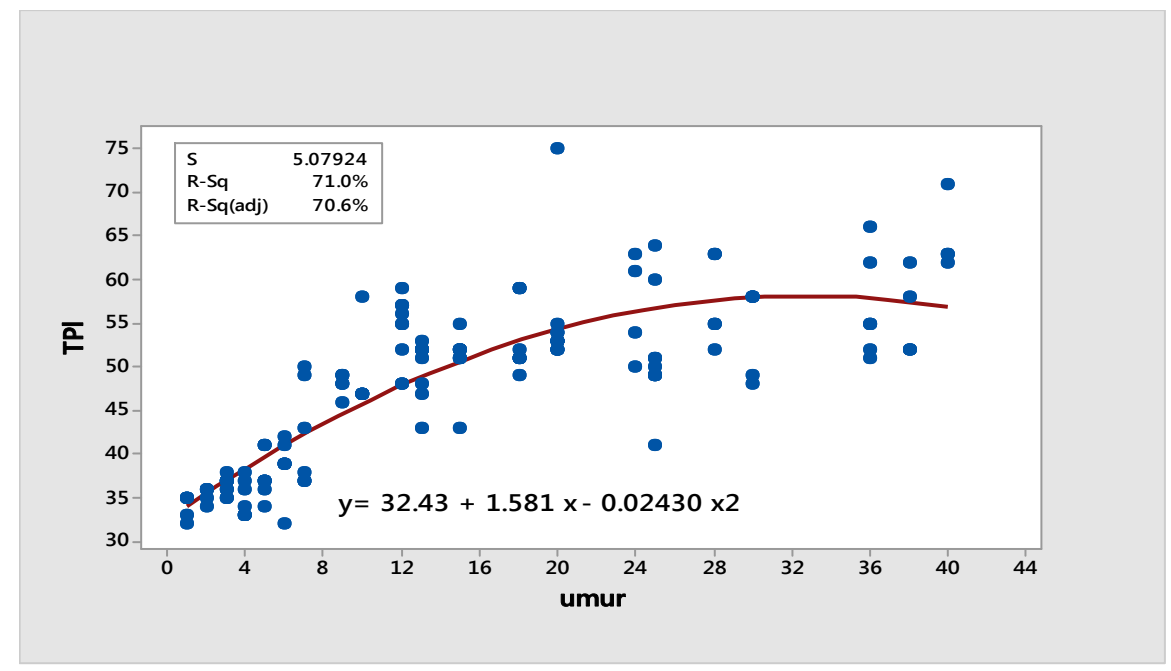

Gambar 5. Kurva pola pertumbuhan tinggi pinggul kambing kacang jantan

\section{KESIMPULAN DAN SARAN}

\section{Kesimpulan}

Dapat disimpulkan bahwa pola pertumbuhan kambing kacang jantan di Kabupaten Konawe Selatan cenderung meningkat seiring bertambahnya umur dan 94,8 \% faktor umur bisa menentukan bobot badan kambing kacang jantan di Konawe Selatan.

\section{Saran}

Pola pertumbuhan ternak kambing dapat diketahui dengan mengukur bagianbagian tubuh (Panjang badan, lingkar dada, tinggi pundak, tinggi pinggul), dan dapat dijadikan dasar seleksi guna perbaikan mutu genetik ternak kambing kacang.

\section{DAFTAR PUSTAKA}

Dewi. A. A. 2013. Hubungan Antara Ukuran-ukuran Tubuh Terhadap Bobot Badan Kambing Jawarandu Betina Umur 0-4 Tahun di Kabupaten Brebes. Fakultas Peternakan Universitas Diponegoro, Semarang (Skripsi).
Marya, D.T. 2011. Keragaan Kualitas Susu Segar dan Mentega berdasarkan Genotipe Gen GH dari kambing Saanen dan Peranakan Etawah. Skripsi. Sekolah Pasca Sarjana. Institut Pertanian Bogor.

Nasution, S., F. Mahmalia. dan M. Doloksaribu. 2010. Pengaruh Musim terhadap Pertumbuhan Kambing Kacang Prasapih di Stasiun Percobaan Lokal Penelitian Kambing Potong Sei Putih. Seminar Nasional Teknologi Peternakan dan Veteriner. 621-625

Rahardian. A. 2014. Hubungan Antara Ukuran-ukuran Tubuh dengan Bobot Badan Kambing Kacang Jantan di Kabupaten Wonogiri. Fakultas Peternakan dan Pertanian Universitas Diponegoro, Semarang (Skripsi)

Sampurna. I. P dan Suatha. I. K. 2010. Pertumbuhan Alometri Dimensi Panjang dan Lingkar Ternak Kambing. Jurnal Veteriner 11.1:4651. Universitas Udayana Bukit. Bali. 
Septian. A.D., M. Arifin dan E. Rianto. 2015. Pola Pertumbuhan Kambing Kacang Jantan di Kabupaten Grobogan. Jurnal Animal Agriculture 4(1): 1-6. Fakultas Peternakan dan Pertanian. Universitas Diponegoro. Semarang.

Siregar, S. B. 1990. Ransum Ternak Ruminansia. Penerbit Swadaya. Jakarta.

Sugiyono. 2010. Metode Penelitian Kuantitatif Kualitatif dan R\&D : Penerbit CV Alafabeta, Bandung.

Sutiyono, B.., N. J. Widyani. Dan E. Purbowati. 2006. Studi Performans Induk Kambing Peranakan Etawa Berdasarkan Jumlah Anak Sekelahiran di Desa Banyuringin Kecamatan Singosari Kabupaten Kendal. Seminar Nasional Teknologi Peternakan dan Veteriner. Hlm. 537-543.

Soeparno. 2009. Ilmu dan Teknologi Daging. Edisi ke-5. Gadjahmada University Press, Yogyakarta
Syawal, S., B. P. Purwanto dan I. G. Permana. 2013. Studi Hubungan Respon Ukuran Tubuh dan Pemberian Pakan Terhadap Pertumbuhan Sapi Pedet dan Dara. JITP 2 :175-188

Tahuk, P.K., E. Baliarti dan H. Hartadi. 2008. Kinerja Kambing Bligon Pada Penggemukan dengan level Protein Pakan Berbeda. Buletin Peternakan 32 (2): 121-135

Tidariyanti, G. 2013. Hubungan Ukuranukuran Tubuh dengan Bobot Badan Kambing Jawarandu Jantan di Kabupaten Brebes. Skripsi. Fakultas Peternakan dan Pertanian Universitas Diponegoro.

Wahyono, T., Kusumaningrum, Widiawati dan Suharyono. 2013. Penampilan Produksi Kambing Kacang Jantan yang diberi Pakan Siap Saji (PSS) Berbasis Silase Tanaman Jagung. Seminar Nasional Teknologi Peternakan dan Veteriner. 363-367 